\title{
メッシュ法による土工量計算の精度に関する研究
}

\author{
村井 俊治* ・大林 成行* \\ 篠田徹**. 高橋 博将 ${ }^{*}$
}

\section{A Study on the Accuracy for Volume Calculation of Earth Works by Mesh Method}

\author{
by S. Murai, S. Ohbayashi, \\ T. Shinoda and H. Takahashi
}

\begin{abstract}
The objectives of the study are stressed on the studies on the errors in volume calculations of earth works by using the mesh method, and on the criteria for determining the optimum mesh intervals.

A test area was applied for the study in which five different mesh intervals, $5 \mathrm{~m}, 10$ $\mathrm{m}, 15 \mathrm{~m}, 20 \mathrm{~m}$, and $30 \mathrm{~m}$ were sampled for the volume calculation.

The results suggest that both absolute error, relative error and the ratio of volume error to the area should be considered in the case of the analysis of errors in volume calculation.
\end{abstract}

要旨：この研究はメッシュ法による土工量計算に生じる䛊差ととの表現方法を考察し，さらに適切なメッシュ間 隔を求める基準について論及することを目的としている。

ここでは䒠験地域による土工量計算を計画高を種々にかえて行った。メッシュ間隔は $5 \mathrm{~m}, 10 \mathrm{~m}, 15 \mathrm{~m}, 20 \mathrm{~m}$ ， $30 \mathrm{~m}$ の 5 種類想定し，それぞれについての誤差の挙動をみようとした。

本研究は実験的研究であって, 実験の絬果からすぐに基準を決定する段階ではないが，メッシュ法による土土量 計算における種々の問題をさぐる上で貴重な実験となるであろう。

まえがき 宅地造成工事やゴルフ場造成工事なぞ面 的に大規模な土工を必要とする工事では, 土工量の出 来高測量が高い精度をもつことが要求される。正確な 土工量計算は，適正な出来高積算に役立つばかりでな く, 正確な土工換算係数を求めることが出来る点で, 土工上の高度な判断と適切な設計変更を可能にする。

従来から, 测量技術者は, 測量によって得られる高 さの精度について，実測と航測の場合の比較をしなが ら数多く論議してきた。しかし土木技術者は, 高さと 面積の積和として間接的に求められる土工量の精度に ついて知りたいのである。

大規模宅地造成工事の出来高測量に, 航空写真測量 と計算機を結びつけてメッシュ方式で能率的に行う方 法が最近めざましい効果を発揮することがわかってき た。この場合, メッシュ点の高さの測定を航空写真測 量で行い, その結果にメッシュ単位面積を掛けて土量 計算を行らのであるが，全体の作業の中でメッシュ点

*東大生産技術研究斦 **条大研究生（帝国測量 K. K. )

$\dagger$ アジア航測K. K.

「写真測量」Vol. 12 No. 11973
の高さを測定する作業がきわめて多い。

メッシュ法では, メッシュ間隔をどのくらいに決め たらよいかが，測定作業に大きく影響する。メッシュ 間隔あるいはメッシュ点数と土工量の精度の関係を知 ることは，適切なメッシュ間隔を定める上できわめて 重要である。

この研究では, メッシュ間隔を変えた場合に, 土工 量の精度がどのように変化するかを, ある地形モデル を用いて求め, 基礎的な考察を行った。また土工量の 精度をあらわす方法についても，二，三の考え方を提 案した。

\section{1. 土工量計算とその誤差}

土工量の計算に一般的に用いられている方法にはつ ぎの三つがある。

\section{(1) 等高線法}

地形がさわめて複雑であり，土工計画面が平坦な場 合に, 土工高の等高線を引き, 等高線に囲まれる土工 面積を各高さ毎に求めてつぎの式により土工量を求め る。 


$$
V=\int S d h \doteqdot\left(\frac{1}{2} s_{1}+s_{2}+\cdots+s_{n-1}+\frac{1}{2} s_{n}\right) \Delta h
$$

この場合，面積の測定を機械化するのがやっかいと なる。

\section{(2) 平均断面法}

一般飞良く用いられる方法で，等距離毎の断面にお ける土工面積を求め, 断面間の平均断面積之距離の積 和により土工量を求める。

$$
V=\int S d l \doteqdot\left(\frac{1}{2} s_{1}+s_{2}+\cdots+s_{n-1}+\frac{1}{2} s_{n}\right) \Delta l
$$

この場合, 面積の計算は, 地形高の測定が機械化さ れれば，機械化することは可能であるが，断面をとる 距離の適切な間隔を定めることが問題となる。

\section{(3) メッシュ法}

面的にひろがりのある宅地造成などに良く用いら れ,メッシュ点汇扮汀る地形高之計画高の差, すなわ ち土工高さにメッシュ単位面積を掛けることによって 土工量計算が行われる。

$$
V=\int h d s \doteqdot \Sigma \Sigma h_{i j} d^{2}
$$

この場合；メッシュ点の地形高を測定することは， 航空写真により容易に機械化できるが，メッシュ間隔 を適切に定めることが問題となる。また境界部に打沽 るメッシュ単位面積を補正しなければならない。

土工量計算に伴なら主な䛊差にはつぎのものが考光 られる。

（1）地形高さの誤差：測量学では中等誤差として士何 $\mathrm{cm}$ と表現している。これは航空写真測量 の場合，基準点の残差の標準偏差をあらわ しているのであって，全地域にこの誤差が あるわけではない。またこの誤差が土工量 の誤差に関連することは分るが，平均的に ぞのよらな関数関係注なるかはわかってい ない。乙かし誤差の平均値の期待值は 0 と なる。

（2）内挿近似の誤差：地形点を無限に多くし て測定することは不可能である。 $5 \mathrm{~m}$ 拈き とか10m拈きなどに 1 点の割合で地形点を とり，その間を内雨近似するために，土工 量計算に誤差を生じる。これは地形高が正 確に測定されていても生じる誤差である。 この研究では, 内挿近似の誤差に注目する ことにして, 測定点の間隔によって土工量 計算がどのように異なるかをみようとし た。したがって地形高の測定は正しいとい ら前提のもとに実際を行った。

（3）面積の䛊差：メッシュ法の場合, 境界部
の単位面積を 1 とすることによる誤差で，辺の部分 は1/2，隅で $1 / 4$ にすなどして補正を行う。全体の中 では大した䛊差にはならない。

つぎに土工量の誤差をどのように表現したらよいか について考光てみよう。土工量の誤差の表現方法とそ の特長を列挙するとつぎのようになる。

(1) 土工量の䛊差の絶対量: $\Delta V=V-V_{t}$

工事の規模によって誤差の絶対量が全体に対して どのような比率を占めるかが，これだけではかから ない。

(2) 土工量の相対誤差: $\alpha=\Delta V / V$

土工量の誤差は主に地表近くの詔差であるから，

土工量が大きくなればなる程，すなわち土工高が大 きくなる程相対䛊差は小さくなる。したがって，土 工量の誤差の絶対量や相対䛊差だけでは, 一般的に

土工量の精度を定義らけることはできない。

(3) 単位面積あたりの土工量誤差: $\Delta h=\Delta V / S$

単位面積あたりの土工量の䛊差，すなわち土工高 の平均的な誤差に換算して土工量の誤差を表現す る。

結局土工量の啡差を裴現する場合には，土工量の誤 差の絶対量だけでなく，土工量および土工面積に対す る比を同時に検討することが必要である。

\section{2. メッシュ法による土工量計算の例}

\section{2-1. モデル地区の地形特性}

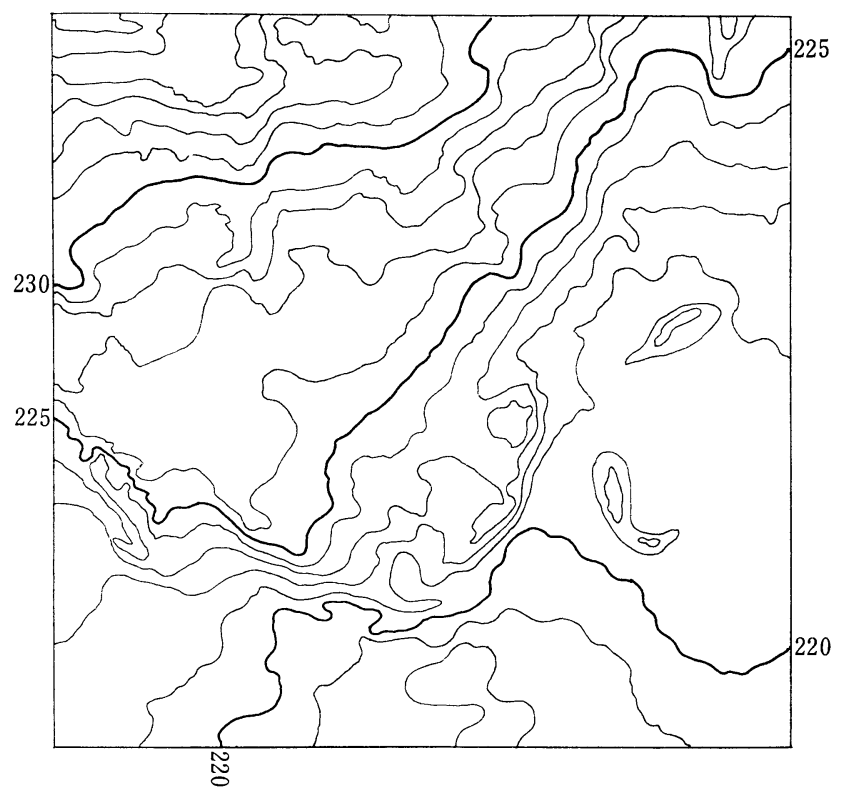

図 1 モデル地区等高線地図 
表 1 （a）土工量計算方法による切土量

\begin{tabular}{|c|c|c|c|}
\hline $\begin{array}{l}\text { 整 } \begin{array}{c}\text { 地 } \\
(\mathrm{m})\end{array} \\
\end{array}$ & 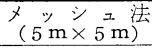 & $\begin{array}{c}\text { 平均 断 面 法 } \\
(5 \mathrm{~m} \text { 間隔 })\end{array}$ & $\begin{array}{l}\text { 等 高線 法 } \\
\text { (2 } 2 \text { m等高線) }\end{array}$ \\
\hline 210.0 & $205,236.2$ & $205,258.8$ & $207,726.6$ \\
\hline 212.0 & $176,450.3$ & $176,459.2$ & $178,926.6$ \\
\hline 214.0 & $147,660.0$ & $147,659.4$ & $150,120.4$ \\
\hline 216.0 & $118,860.0$ & $118,859.9$ & $121,330.6$ \\
\hline 218.0 & $90,078.8$ & $90,074.3$ & $92,756.0$ \\
\hline 220.0 & $63,257.1$ & $63,246.6$ & $66,189.1$ \\
\hline 222.0 & 42.879 .5 & $42,830.7$ & $45,025.6$ \\
\hline 224.0 & $27,610.8$ & $27,545.3$ & $29,409.1$ \\
\hline 226.0 & $15,848.2$ & $15,800.6$ & $17,446.6$ \\
\hline 228.0 & $8,618.4$ & $8,590.1$ & $9,376.6$ \\
\hline 230.0 & $4,064.6$ & $4,042.4$ & $4,574.1$ \\
\hline 232.0 & $1,530.8$ & $1,524.1$ & $1,799.0$ \\
\hline 234.0 & 441.9 & 435.2 & 459.1 \\
\hline 236.0 & 35.7 & 33.4 & 51.0 \\
\hline 238.0 & 0.0 & 0.0 & 0.0 \\
\hline 240.0 & 0.0 & 0.0 & 0.0 \\
\hline
\end{tabular}

いま図1に示すよらな $120 \mathrm{~m} \times 120 \mathrm{~m}=1.44$ ha のモ デル地区を $5 \mathrm{~m}$ 正方の格子状のメッシュをかけ，それ ぞれの地形高を写真測量により測定した。

このとき，このモデル地区の地形の平均地盤高は $224.27 \mathrm{~m}$ ，標準偏差は土4.41mであった。

***** PH=222.0 *****

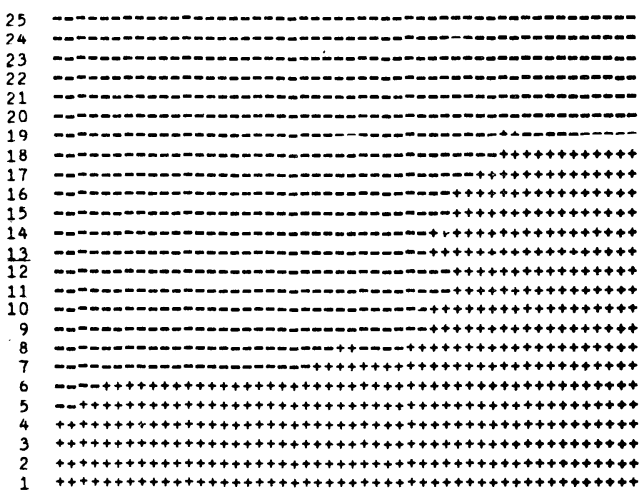

***** PH=224.0 *****
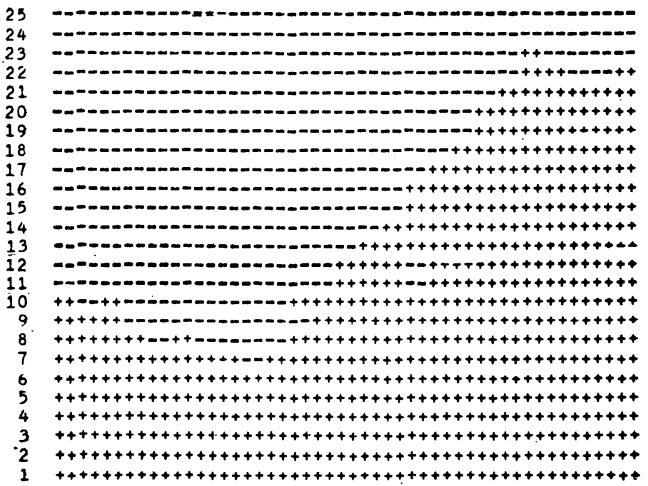

表 1 (b) 土工量計算方法による盛土量

\begin{tabular}{|c|c|c|c|}
\hline $\begin{array}{c}\text { 整 } \underset{(\mathrm{m})}{\text { 高 }} \\
(\mathrm{m})\end{array}$ & 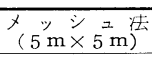 & $\begin{array}{c}\text { 平均 断 面法 } \\
(5 \mathrm{~m} \text { 間隔 })\end{array}$ & $\begin{array}{l}\text { 等高線 法 } \\
\text { (2 } 2 \text { m等繶線 }) \\
\end{array}$ \\
\hline 210.0 & 0.0 & 0.0 & 0.0 \\
\hline 212.0 & 0.0 & 0.0 & 0.0 \\
\hline 214.0 & 0.0 & 0.0 & 0.0 \\
\hline 216.0 & 0.0 & 0.0 & 0.0 \\
\hline 218.0 & 18.7 & 13.8 & 250.0 \\
\hline 220.0 & $1,996.7$ & $1,985.8$ & $2,002.5$ \\
\hline 222.0 & $10,418.5$ & $10,369.6$ & $9,640.0$ \\
\hline 224.0 & $23,949.4$ & $23,883.8$ & $22,822.5$ \\
\hline 226.0 & $40,986.6$ & $40,938.9$ & $39,6 \in 0.0$ \\
\hline 228.0 & $62,556.2$ & $62,528.1$ & $60,3 \subseteq 0.0$ \\
\hline 230.0 & $86,790.4$ & $86,779.5$ & $84,287.5$ \\
\hline 232.0 & $113,048.8$ & $113,061.1$ & $110,312.5$ \\
\hline 234.0 & $140,756.1$ & $140,772.1$ & $137,772.5$ \\
\hline 236.0 & $169,147.4$ & $169,169.6$ & $166,087.5$ \\
\hline 238.0 & $197,910.1$ & $197,935.7$ & $194,836.9$ \\
\hline 240.0 & $226,709.1$ & $226,735.0$ & $223,636.9$ \\
\hline
\end{tabular}

この地形を一平面台地に整地することを考え，整地 計画高を $210.0 \mathrm{~m}$ から $240.0 \mathrm{~m}$ までの間を $2.0 \mathrm{~m}$ の間隔 で合計16通り想定し，それぞれの整地に要する土工量 を算定した。表 1 は，土工量計算を $5 \mathrm{~m}$ メッシュを用 いたメッシュ法， $5 \mathrm{~m}$ 間隔の平均断面法，プラニメー

*****PH=226.0*****

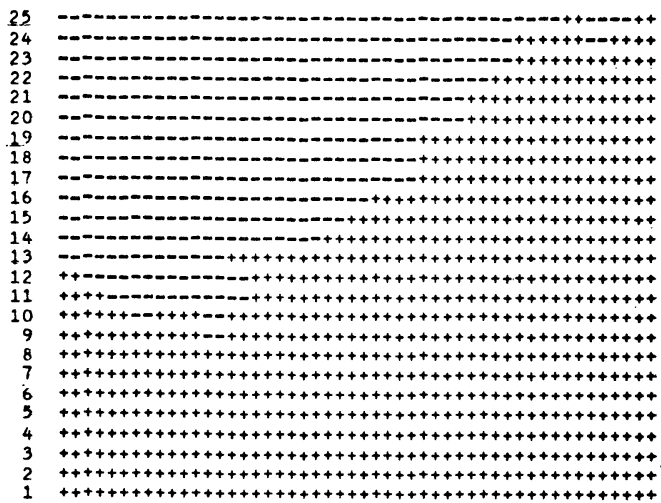

***** PH=228.0 *****

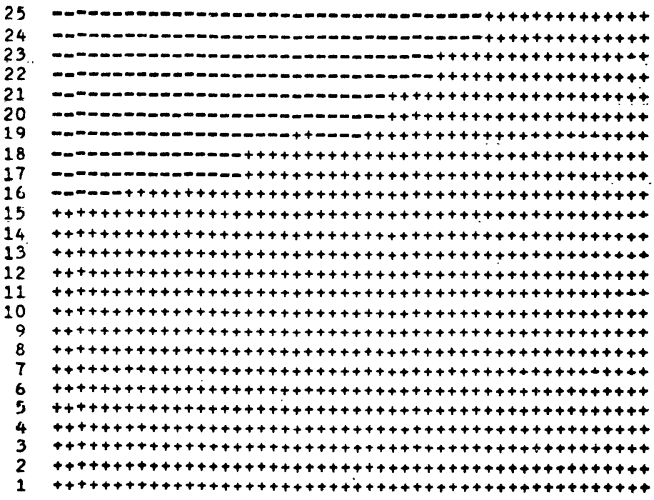

図 2 メッシュ法による切盛土量および切盛土面積 
タで $2 \mathrm{~m}$ 等高線を追跡した等高線法による值をあげた ものである。

図 2 はメッシュ法による切土量, 盛土量および切土 面積，盛土面積の計算結果を図示したものである。

\section{2-2. メッシュ間隔の相違による土工量誤差}

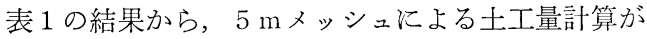
十分真值に近いと考えてよい。実際の土木工事の測量 方法からみても，も乙地形高が正しいと仮定すれば，

表 2 メッシュ法による土工量計算

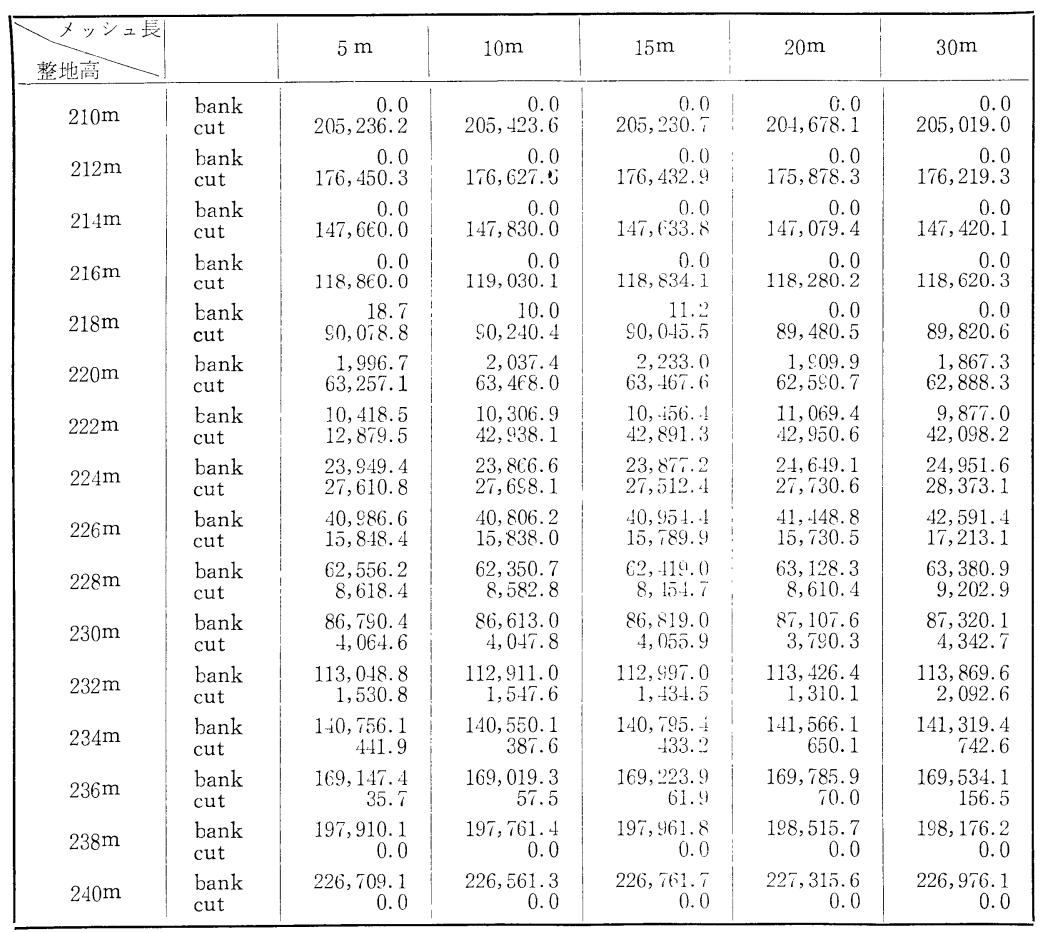

$5 \mathrm{~m}$ メッュは十分すぎる程密度の大きい配置である からほぼ正確な土工量が出たと考えられる。

$5 \mathrm{~m}$ 間隔で分割したメッシュから，10m，15m，20 $\mathrm{m}, 30 \mathrm{~m}$ 間隔の地形点を抽出し，メッシュの大きさを 変えて表 2 に示すように土工量計算を行ってみた。こ のとき， $5 \mathrm{~m}$ メシュの土工量との差，相対詋差，お よび単位土工面積あたりの土工量誤差を，切土量和よ び盛土面について求めた（表 3 参照）。

表 3 から，つぎに列挙するよらな特徴を見いだすこ とができる。

(1) メッシュ間隔が粗くな る程, 土工量の誤差の最 大值は増加してゆく。

(2) メッシュ間隔が粗くな る程，土工量の䛊差のば らつきが増大する。

(3) 土工量の小さいところ では，相対䛊差が大きく なる。これは,メッシュ 点数が少ないために拈き る。

(4) メッシュ間隔が粗くな る程, 土工量の絶対誤差, 相対誤差，土工高䛊差と もに大きくなる傾向があ る。

（5）切土量および盛土量の 絶対誤差はそれぞれのメ ッシュ間隔で汪ぼ同じよ らな特性を示す。

表 3（a）土工量 誤差（切土）

\begin{tabular}{|c|c|c|c|c|c|c|c|c|c|c|c|c|}
\hline \multirow{2}{*}{ 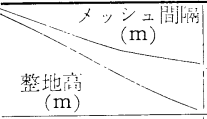 } & \multicolumn{3}{|c|}{10.0} & \multicolumn{3}{|c|}{15.0} & \multicolumn{3}{|c|}{20.0} & \multicolumn{3}{|c|}{30.0} \\
\hline & $a$ & $b$ & $c$ & $a$ & $b$ & $c$ & $a$ & $b$ & $c$ & $a$ & $b$ & $c$ \\
\hline 210.0 & 187.4 & 0.091 & 13.0 & 5.5 & 0.002 & 0.3 & 558.1 & 0.271 & 38.7 & 217.2 & 0.105 & 15.0 \\
\hline 212.0 & 177.3 & 0.100 & 12.3 & 17.4 & 0.009 & 1.2 & 572.0 & 0.324 & 39.7 & 231.0 & 0.130 & 16.0 \\
\hline 214.0 & 170.0 & 0.115 & 11.8 & 26.2 & $0.01 \%$ & 1.8 & 580.6 & 0.393 & 40.3 & 239.9 & 0.162 & 16.6 \\
\hline 216.0 & 170.1 & 0.143 & 11.8 & 25.9 & 0.021 & 1.8 & 579.8 & 0.487 & 40.2 & 239.7 & 0.201 & 16.6 \\
\hline 218.0 & 161.6 & 0.179 & 11.2 & 33.3 & 0.036 & 2.3 & 598.3 & 0.664 & 41.5 & 258.2 & 0.286 & 17.9 \\
\hline 220.0 & 210.9 & 0.333 & 16.9 & 210.5 & 0.332 & 17.9 & 666.4 & 1.068 & 53.9 & 368.8 & 0.583 & 32.0 \\
\hline 222.0 & 58.6 & 0.136 & 6.8 & 11.8 & $0.02 \tau$ & 4.3 & 71.1 & 0.165 & 8.6 & 781.3 & 1.822 & 90.4 \\
\hline 224.0 & $8 \pi .3$ & 0.316 & 12.4 & 98.4 & 0.356 & 11.6 & 119.8 & 0.433 & 18.5 & 762.3 & 2.760 & 120.3 \\
\hline 226.0 & 10.4 & 0.065 & 1.9 & 58.5 & 0.369 & 6.4 & 117.9 & 0.743 & 23.5 & $1,364.7$ & 8.610 & 263.2 \\
\hline 228.0 & 35.6 & 0.413 & 11.6 & 163.7 & 1.899 & 42.8 & 8.0 & 0.092 & 2.4 & 584.5 & 6.782 & 169.1 \\
\hline 230.0 & 16.8 & 0.433 & 7.8 & 8.7 & 0.214 & 4.4 & 274.3 & 6.748 & 116.6 & 278.1 & 6.8 .42 & 120.7 \\
\hline 232.0 & 16.8 & 1.097 & 15.1 & 96.3 & 0.568 & 90.2 & 220.7 & 17.91 & 187.7 & 561.8 & 18.16 & 487.6 \\
\hline 234.0 & 54.3 & 12.28 & 91.6 & 8.7 & 1.968 & 16.3 & 208.2 & 47.11 & 354.2 & 300.7 & 68.04 & 261.0 \\
\hline 236.0 & 21.8 & 61.06 & 127.9 & 26.2 & 73.38 & 73.6 & 34.3 & 96.07 & 116.7 & 121.8 & 341.1 & 211.4 \\
\hline 238.0 & 0 & 0 & 0 & 0 & 0 & 0 & 0 & 0 & 0 & 0 & 0 & 0 \\
\hline 240.0 & 0 & 0 & 0 & 0 & 0 & 0 & 0 & 0 & 0 & 0 & 0 & 0 \\
\hline
\end{tabular}


(6) $10 \mathrm{~m}$ 間隔および $15 \mathrm{~m}$ 間隔のときの絶対䛊差の最大 值はほぼ $200 \mathrm{~m}^{3}$ で，両者にそれ程の有意差はない。 これに対し $20 \mathrm{~m}$ 間隔のときの絶対誤差の最大值は約 $670 \mathrm{~m}^{3}$ であり, $30 \mathrm{~m}$ 間隔のときは約 $1,500 \mathrm{~m}^{3}$ となり， あきらかに，10m間隔特よび $15 \mathrm{~m}$ 間隔のときの誤差 と有意差が生じる。

（7）土工高の誤差は，土工量が大きくなるにつれ，一 定值に近つく。

（8）相対誤差は，土工量が大きくなるにつれ，小さく なる。

\section{3. メッシュ法におけるメッシュ間隔決定の}

\section{基準}

土工量計算のために，適切なメッシュ間隔を決定し たい。前にあげた例では $15 \mathrm{~m}$ 間隔より小さい間隔と 20 $\mathrm{m}$ 間隔以上の間隔では大きな有意差があり，もし精度 を上げたいのであれば，15m間隔にすればよい。しか 乙，20m間隔ではいけないかといらと，それは誤差の 許容基準をどうとるかによって決めなければいけな い。また，この地形モデルでは，上記の結果になって も他のモデルでは異なる結果になるかも知れない。

このように，今回行った数少ない点数による実験の みでは，適正なメッシュ間隔を決定する基準すでを決 めることはできない。しかしながら，今回の実験を通 じて，きわめて土木技術的立場からつぎのような考え 方が可能である。

（1）現在までに，プラニメータによる面積測定が公認

されていたことから考觉ると，表 1 に見る如く，こ のモデルの場合, $1,000 \mathrm{~m}^{3}$ 以下程度の絶対誤差量に 入っていれば十分である。すなわち，表 3 から $20 \mathrm{~m}$
メッシュ間隔までは許容しらるといえる。

(2) 土工量が $10,000 \mathrm{~m}^{3}$ 以上あるところの相対誤差が約 $1 \%$ 以下であれば土工工学的には十分であろら。す なわちこのモデルの場合, 切土の場合 $222 \mathrm{~m}$ 以下, 盛土の場合 $228 \mathrm{~m}$ 以上の整地高のときが，土工量が 10,000 $\mathrm{m}^{3}$ こえる。したがって約 $1 \%$ 以下のメッシ 二間隔は $20 \mathrm{~m}$ 間隔までとなる。表 1 のプラニメータ の結果では，10, $000 \mathrm{~m}^{3}$ 以上の土工量のとき，約 $2 \%$ ないし $3 \%$ 程度の相対䛊差があるので，1\%の基準 值は，プラニメータの測定より高い精度を目標とし ている。

（3）土木工事的な見方をすれば，土工量が $10,000 \mathrm{~m}^{3} を$ こえる規模のところでは，土工高の誤差が $50 \mathrm{~mm}$ こえては信頼性がきわめて悪いといってよい。

すなわち，このモデルに拈いては，20m間隔がこ の基準值とほぼ等しく，30m間隔以上は信頼性がう すいといえる。

上記のことから，このモデルでは，高い精度を望む 場合には $15 \mathrm{~m}$ 間隔にすればよい。これを $10 \mathrm{~m}$ 間隔にし てもそれ程精度は高くならない。

また，土木工学的には，20m間隔でもなんとか許容 しうるであろう。しかしこの場合，高い精度は望めな い。 $30 \mathrm{~m}$ 間隔は, 土木工学の常識では許容できない, といってよい。しかし，ここでは工事測量を想定して 議論しているので，このような結論を下したが，計画 や設計の段階では当然上記の基準も緩和しなければな らない。

\section{4. メッシュ法における面皘の誤差}

表 3 （b）土 工 量 誤 差（盛 土）

\begin{tabular}{|c|c|c|c|c|c|c|c|c|c|c|c|c|}
\hline \multirow{2}{*}{$\underbrace{}_{\substack{\text { 整地高 } \\
(\mathrm{m})}}$} & \multicolumn{3}{|c|}{10.0} & \multicolumn{3}{|c|}{15.0} & \multicolumn{3}{|c|}{20.0} & \multicolumn{3}{|c|}{30.0} \\
\hline & $a$ & $b$ & $c$ & $a$ & $b$ & $c$ & $a$ & $b$ & $c$ & $a$ & $b$ & $c$ \\
\hline 210.0 & 0 & 0 & 0 & 0 & 0 & 0 & 0 & 0 & 0 & 0 & 0 & 0 \\
\hline 212.0 & 0 & 0 & 0 & 0 & 0 & 0 & 0 & 0 & 0 & 0 & 0 & 0 \\
\hline 214.0 & 0 & 0 & 0 & 0 & 0 & 0 & 0 & 0 & 0 & 0 & 0 & 0 \\
\hline 216.0 & 0 & 0 & 0 & 0 & 0 & 0 & 0 & 0 & 0 & 0 & 0 & 0 \\
\hline 218.0 & 8.7 & 46.52 & 102.4 & 7.5 & 40.10 & 42.1 & 18.7 & 100.0 & 63.6 & 18.7 & $1,380.7$ & 32.4 \\
\hline 220.0 & 40.7 & 2.038 & 20.7 & 236.3 & 11.83 & 88.6 & 86.8 & 4.347 & 42.1 & 129.4 & 6.480 & 44.9 \\
\hline 222.0 & 111.6 & 1.071 & 18.9 & 37.9 & 0.363 & 10.6 & 650.9 & 6.247 & 105.4 & 541.5 & 5.197 & 94.0 \\
\hline 224.0 & 82.8 & 0.345 & 11.1 & ז2.2 & 0.301 & 10.6 & 699.7 & 2.921 & 88.1 & $1,002.2$ & 4. 184 & 124.2 \\
\hline 226.0 & 180.4 & 0.440 & 20.1 & 32.2 & 0.078 & 1.1 & 462.2 & 1.127 & 49.1 & $1,604.8$ & 3.915 & 174.1 \\
\hline 228.0 & 205.5 & 0.328 & 18.1 & 137.2 & 0.219 & 3.1 & 572.1 & 0.914 & 51.2 & 824.7 & 1.318 & 75.3 \\
\hline 230.0 & 177.4 & 0.204 & 14.4 & 28.6 & 0.032 & 2.2 & 317.2 & 0.365 & 26.3 & 529.7 & 0.610 & 47.3 \\
\hline 232.0 & 137.8 & 0.121 & 10.3 & 51.8 & 0.045 & 3.8 & 377.6 & 0.334 & 28.5 & 820.8 & 0.726 & 61.9 \\
\hline 234.0 & 206.0 & 0.146 & 14.9 & 39.3 & 0.027 & 2.8 & 810.0 & 0.575 & 58.6 & 563.3 & 0.400 & 42.5 \\
\hline 236.0 & 128.1 & 0.075 & 9.0 & 76.5 & 0.045 & 5.4 & 638.5 & 0.377 & 45.2 & 386.7 & 0.228 & 27.9 \\
\hline 238.0 & 148.7 & 0.075 & 10.3 & 51.7 & 0.026 & 3.5 & 605.6 & 0.305 & 42.0 & 266.1 & 0.134 & 18.4 \\
\hline 240.0 & 147.8 & 0.065 & 10.2 & 52.6 & 0.023 & 3.6 & 606.5 & 0.265 & 42.1 & 267.0 & 0.117 & 18.5 \\
\hline
\end{tabular}


表 4 メッシュ法における面積差（単位 $\mathrm{m}^{2}$ )

\begin{tabular}{|c|c|c|c|c|c|}
\hline 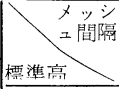 & $5 \mathrm{M}$ & $10 \mathrm{M}$ & $15 \mathrm{M}$ & $20 \mathrm{M}$ & $30 \mathrm{M}$ \\
\hline $216 \mathrm{~m}$ & $\begin{array}{r}14,400.00 \\
0.00\end{array}$ & 0.00 & 0.00 & 0.00 & 0.00 \\
\hline 218 & $\begin{array}{r}14,187.50 \\
212.50\end{array}$ & $\begin{array}{l}+12.50 \\
-12.50\end{array}$ & $\begin{array}{l}-125.00 \\
+125.00\end{array}$ & $\begin{array}{l}+12.50 \\
-12.50\end{array}$ & $\begin{array}{l}+212.50 \\
-212.50\end{array}$ \\
\hline 220 & $\begin{array}{r}12,331.25 \\
2,068.75\end{array}$ & $\begin{array}{l}+43.75 \\
-43.75\end{array}$ & $\begin{array}{l}-350.00 \\
+350.00\end{array}$ & $\begin{array}{l}+368.75 \\
-368.75\end{array}$ & $\begin{array}{l}-406.25 \\
+406.25\end{array}$ \\
\hline 222 & $\begin{array}{l}8,550.00 \\
5,850.00\end{array}$ & $\begin{array}{l}+100.00 \\
-100.00\end{array}$ & $\begin{array}{l}+225.00 \\
-225.00\end{array}$ & $\begin{array}{l}-150.00 \\
+150.00\end{array}$ & $\begin{array}{l}+450.00 \\
-450.00\end{array}$ \\
\hline 224 & $\begin{array}{l}6,600.00 \\
7,800.00\end{array}$ & 0.00 & $\begin{array}{l}-300.00 \\
+300.00\end{array}$ & 0.00 & $\begin{array}{r}-300.00 \\
+300.00\end{array}$ \\
\hline 226 & $\begin{array}{l}4,856.25 \\
9,543.75\end{array}$ & $\begin{array}{l}+68.75 \\
-68.75\end{array}$ & $\begin{array}{r}-75.00 \\
+75.00\end{array}$ & $\begin{array}{l}-156.25 \\
+156.25\end{array}$ & $\begin{array}{l}318.75 \\
318.75\end{array}$ \\
\hline 228 & $\begin{array}{r}2,806.25 \\
11,593.75\end{array}$ & $\begin{array}{l}-181.25 \\
+181.25\end{array}$ & $\begin{array}{l}+175.00 \\
-175.00\end{array}$ & $\begin{array}{l}-305.25 \\
+306.25\end{array}$ & $\begin{array}{l}568.75 \\
568.75\end{array}$ \\
\hline 230 & $\begin{array}{r}1,743.75 \\
12,656.25\end{array}$ & $\begin{array}{r}-18.75 \\
+18.75\end{array}$ & $\begin{array}{l}-112.50 \\
+112.50\end{array}$ & $\begin{array}{l}+156.25 \\
-156.25\end{array}$ & $\begin{array}{r}-168.75 \\
+168.75\end{array}$ \\
\hline 232 & $\begin{array}{r}793.75 \\
13,606.25\end{array}$ & $\begin{array}{r}-18.75 \\
+18.75\end{array}$ & $\begin{array}{l}+50.00 \\
-50.00\end{array}$ & $\begin{array}{l}-293.75 \\
+293.75\end{array}$ & $\begin{array}{l}-118.75 \\
+118.75\end{array}$ \\
\hline 234 & $\begin{array}{r}343.75 \\
14,056.25\end{array}$ & $\begin{array}{l}+131.25 \\
-131.25\end{array}$ & $\begin{array}{r}-62.50 \\
+62.50\end{array}$ & $\begin{array}{r}-43.75 \\
+43.75\end{array}$ & $\begin{array}{l}+331.25 \\
-331.25\end{array}$ \\
\hline 236 & $\begin{array}{r}93.75 \\
14,306.25\end{array}$ & $\begin{array}{r}-18.75 \\
+18.75\end{array}$ & $\begin{array}{r}+75.00 \\
-75.00\end{array}$ & $\begin{array}{r}+6.25 \\
-6.25\end{array}$ & $\begin{array}{l}+131.25 \\
-131.25\end{array}$ \\
\hline 238 & $\begin{array}{r}0.00 \\
14,400.00\end{array}$ & 0.00 & 0.00 & 0.00 & 0.00 \\
\hline 標準偏差 & & 137.47 & 271.95 & 297.78 & 361.68 \\
\hline
\end{tabular}

メッシュ法による土工量計算の中に介入する誤差の 一つに面積の誤差に起因するものがある。対象区域が 全面積にわたって切土または盛土になるところではこ の誤差は介入しない。対象地域の中に切土と盛土の区 域が混在しているところでは, メッシュ間隔の粗密の 程度で, 切土面積または盛土面積に誤差を生じるわけ である。したがって，全地域が切土または盛土になる 場合，たとえば前述の例では計画高が $216.0 \mathrm{~m}$ 以下ま たは $238.0 \mathrm{~m}$ 以上のところでは, 絶対誤差量が一定值 になる。すなわち, メッシュ間隔の違いによるサンプ リング個数とその土工差が，真実の地形にどの程度近 似するかによってその誤差に差違を生じる。したがっ て地形の起伏がたとえば $20 \mathrm{~m}$ 程度の周期波になってい れば，20m毎に波の山頂部があらわれるので，もし20 mメッシュにすれば誤差は一方に傾く結果になる。

切土と盛土が混在するところ，すなわち前例では 218.0mから $236.0 \mathrm{~m}$ をでの間では，上記の誤差のほか に面積による誤差が加えられるので, 当然䛊差のばら つきも大きくなる。

表 4 はメッシュ間隔 $5 \mathrm{~m}$ の場合の切土面積および盛 土面積と， $10 \mathrm{~m} ， 15 \mathrm{~m}, 20 \mathrm{~m}, 30 \mathrm{~m}$ のメッシュ間隔の ときの土工面積との䛊差をあらわしている。また 218.0 mから $236.0 \mathrm{~m}$ までの䛊差の標準偏差も計算した。

この表から以下のことがいえる。

(1) メッシュ間隔が粗になる程, 䛊差の最大值, 標準 偏差は増大する。

（2）切土面積と盛土面積が混在しているところでは, その面積の大小に関係なく, 誤差が生じる。

(3) $15 \mathrm{~m}$ と $20 \mathrm{~m}$ のッシュ間隔のとさの誤差の大小に は有意差がない。

(4) 表 3 の土工量の誤差と比較すると, 土工量の誤差 も切土と盛土が混在するところでとの最大值をと る。しかし, 最大值の生じるところが土工量と面積 の愦差の場合で必ずしも一致しない。

\section{むすび}

本研究は, メッシュ法による土工量計算の䛊差に伴 なら疑問点を卒直にとりあげ，実験的な研究を行っ た。それ故, この種の問題に対する一つの問題提起に もなっている。ここで行った実験は必ずしも十分なサ ンプリング個数があったわけでもなく，とりあげた地 形が典型的なものといえるものでもないが，この実験 に出てきた䛊差の傾向は, 従来から想定していた一般 的な傾向にかなり類似していたといえる。

今後さらに数多くの実験をかさね, 地形のタイプに 対応した適切なメッシュ間隔を決める基準を定めたい と考えている。 